\title{
NEW FIELD INVESTIGATIONS OF THE ILÍMAUSSAQ KAKORTOKITE
}

\author{
C. K. Brooks and H. Bohse
}

The summer season of 1968 was spent at Kangerdluarssuk where detailed investigations of the stratigraphy of the layered kakortokite, first described by Ussing (1912), were made. It is intended that this work should form the basis for detailed petrological and geochemical investigations aimed at gaining some insight into the mechanisms of formation of this remarkable series of igneous cumulates which has already been studied in some detail by Ferguson (in press).

The field work was begun by selecting a suitable traverse for a collection of the entire exposed sequence. About twenty-eight units, each consisting of a black, red and white layer as described by Ussing (1912), were recognised and wherever possible a representative sample was taken from each.

The preparation of a detailed map of the kakortokite was greatly assisted by the early recognition of two distinctive red horizons, one which was used as a datum about ten units above the lowest exposed unit, and another near the top underlain by a syenite porphyry sill and showing marked fine-scale layering. Both layers are comparatively thick, very rich in eudialyte and may easily be traced throughout the entire kakortokite outcrop. Another distinctive layer consists of crushed kakortokite and has apparently formed by shearing along the plane between two units shortly after consolidation. This layer covers large areas at the base of the exposed series but is comparatively thin.

A number of inclusions of augite syenite noted by previous workers (Ussing, 1912, Sørensen, 1958, Ferguson, 1964) were shown by the mapping to be confined to one horizon which is found at sea level in one place but may rise to as high as $300 \mathrm{~m}$ above sea level.

The exact relationship between the kakortokite and the lujavrites has not been established, but no sign of the fault postulated by Ferguson (1964) could be found and it is now believed that there may be a lateral transitional 
relationship between the two. However, a more definite answer, both to this problem and others raised by the work, must await the results of laboratory work and further field work in 1969 when it is planned to investigate the more easterly areas of kakortokite on Laksefjeld.

Field work was carried out in close association with Dansk Svovlsyre- og Superphosphat-Fabrik A/S who are at present investigating possible commercial uses of the kakortokite.

References

Ferguson, J. (1964) Geology of the Ilímaussaq alkaline intrusion, South Greenland. Bull. Grфnlands geol. Unders., No. 39 (also Meddr Grфnland, Bd. $172, \mathrm{Nr} .4$.

Ferguson, J. (in press) The significance of the kakortokite in the evolution of the Ilímaussaq intrusion, South Greenland. Meddr Gr $\phi$ nland, Bd. 186, Nr. 5 .

Sфrensen, H. (1958) The Ilímaussaq batholith, a review and discussion. Bull. Grфnlands geol. Unders., No. 19 (also Meddr Grønland, Bd. 162, Nr. 3)。

Ussing, N. V. (1912) Geology of the country round Julianehaab, Greenland. Meddr Grфnland, Bd. 38. 